\title{
STUDY OF SERUM PHOSPHORUS AND CALCIUM LEVELS IN PATIENTS UNDERGOING MAINTENANCE HAEMODIALYSIS
}

\author{
Ranjeet Kumar'1, Varunkumar Doddegowda², Gurupadappa Kallaganad ${ }^{3}$ \\ ${ }_{1}^{1}$ Post Graduate Student, Department of Biochemistry, Shimoga Institute of Medical Sciences, Shivamogga. \\ ${ }^{2}$ Assistant Professor, Department of Biochemistry, Shimoga Institute of Medical Sciences, Shivamogga. \\ 3Professor \& HOD, Department of Biochemistry, Shimoga Institute of Medical Sciences, Shivamogga.
}

\begin{tabular}{l}
\hline ABSTRACT \\
\hline BACKGROUND \\
In many countries, nephrologists follow clinical practice guidelines for mineral bone disorders to control abnormal serum \\
Calcium (Ca) and Phosphorus (P) levels in patients undergoing Maintenance Haemodialysis (MHD). Abnormalities of calcium and \\
phosphorous are associated with cardiovascular morbidity, mortality and also with mineral bone disease. The Kidney Disease \\
Outcomes Quality Initiative (KDOQI) Guidelines have long been used. Hence, this study was undertaken to investigate the current \\
status of serum Ca and P control in MHD patients.
\end{tabular}

\section{METHODS}

The case control study comprised of 45 subjects undergoing MHD without intercurrent illness from McGann Teaching Hospital, SIMS, Shivamogga. Serum levels of Calcium and Phosphorus were measured and their product was calculated.

\section{RESULTS}

The mean values of the serum Calcium in the subjects was significantly lower $(7.75 \pm 0.74 \mathrm{mg} / \mathrm{dL})$ than that of the control group $(9.81 \pm 0.52) \mathrm{p}<0.001$, whereas the mean values of the serum phosphorus in the subjects was higher $(5.74 \pm 1.35)$ than that of the controls $(3.91 \pm 0.41)$ with a $\mathrm{p}<0.001$. However, the percentage of patients with $\mathrm{Ca}, \mathrm{P}$ and CaXP product levels within the KDOQI guideline ranges were $11 \%, 4 \%, 89 \%$, respectively.

\section{CONCLUSION}

Despite the current clinical practice guidelines, serum mineral levels were inadequately controlled in many MHD patients. Because these mineral abnormalities are associated with mineral bone disease and cardiovascular mortality, adequate management of mineral abnormalities should be promptly done in these patients.

\section{KEYWORDS}

CKD, Mineral Metabolism, Vascular Calcification.

HOW TO CITE THIS ARTICLE: Kumar R, Doddegowda V, Kallaganad G. Study of serum phosphorus and calcium levels in patients undergoing maintenance haemodialysis. J. Evolution Med. Dent. Sci. 2016;5(36):2092-2095, D0I: 10.14260/jemds/2016/491

\begin{abstract}
INTRODUCTION
Hyperphosphatemia has emerged as an important clinical issue in dialysis patients. These patients will have more of $\mathrm{CV}$ morbidity and mortality. Further to improve the management of patients, determination of serum phosphorus levels and calcium phosphorus product will help the clinician in refining the lives of thousands of kidney dialysis patients. Higher levels of serum Phosphorus (P) and Calcium-Phosphorus Product (Ca X P) have now been associated with increased vascular calcification, which may lead to cardiovascular mortality.[1-6]

To improve the quality of care in patients undergoing maintenance haemodialysis, clinical practice guidelines have been developed and used in many countries. Globally, the Kidney Disease Outcome Quality Initiative (KDOQI) and Kidney Disease: Improving Global Outcomes (KDIGO) guidelines are popular.[7,8]
\end{abstract}

Financial or Other, Competing Interest: None.

Submission 19-03-2016, Peer Review 14-04-2016,

Acceptance 21-04-2016, Published 03-05-2016.

Corresponding Author:

Dr. Varunkumar Doddegowda,

Assistant Professor,

Department of Biochemistry,

Shimoga Institute of Medical Sciences,

Sagar Road, Shivamogga-577201.

E-mail:drvarun7@gmail.com

DOI: $10.14260 /$ jemds $/ 2016 / 491$
In the Asia-Pacific area, Australia and Japan have their own guidelines for CKD-Mineral Bone Disorder (MBD) management (Caring for Australasians with Renal Impairment [CARI] and Japanese Society for Dialysis Therapy [JSDT] guidelines, respectively).[9,10] In these guidelines, target ranges for serum minerals have been recommended for the optimal management of patients undergoing MHD.

In Europe, America and Japan, epidemiologic studies have been conducted in patients with MHD and demonstrated association between abnormal mineral metabolisms based on patient serum mineral levels and patient outcomes.[11-13]

We aimed to evaluate serum mineral levels in patients undergoing MHD to check whether these patients are optimally managed. These results may provide insight into the status of current practice in the era of such guidelines.

\section{MATERIAL AND METHODS}

This case control study comprised of 45 patients undergoing MHD matched with equal number of healthy controls from McGann Teaching Hospital attached to SIMS, Shivamogga.

Enrolment criteria included was as per the KDOQI guidelines. (1) Patient age $>18$ years, (2) CKD stage 3-5 on chronic haemodialysis for $>6$ months. Patients with intercurrent illnesses requiring hospitalization were excluded. Patient demographic data were obtained along with the consent from as required by the Institutional Ethics Committee. 
The quantitative determination of serum phosphorus was done using Beacon Diagnostic Kit on Transasia XL-640 fully automated chemistry analyzer. The phosphate ions in an acidic medium react with ammonium molybdate to form a phosphomolybdate complex. This complex has an absorbance in the ultraviolet range and is measured at $340 \mathrm{~nm}$, the intensity being proportional to the concentration present in the sample.

The quantitative determination of serum calcium was done using Biosystems S A Kit on Transasia XL-640 fully automated chemistry analyzer. The calcium in the sample reacts with Arsenazo III forming coloured complex that is measured at $650 \pm 20 \mathrm{~nm}$, the intensity being proportional to the concentration present in the sample.

Continuous data are presented as mean \pm standard deviation and categorical variables are expressed as frequency counts and percentages.

\section{RESULTS}

Present study included 45 patients of CKD who were on MHD for more than 6 months. Same number of age and sex matched healthy subjects were included as controls. Of the 45 patients, $37(82 \%)$ were males and $8(8 \%)$ were females. The mean age of the patients is 47.68 years with an SD of 13.06 .

The mean phosphorus levels in patients are $5.74 \mathrm{mg} / \mathrm{dL}$ with an SD $\pm 1.35 \mathrm{mg} / \mathrm{dL}$, mean calcium levels are $7.75 \mathrm{mg} / \mathrm{dL}$ with an SD $\pm 0.74 \mathrm{mg} / \mathrm{dL}$ and mean Ca X P (Calcium Phosphorus Product) is 44.15 with a $\mathrm{SD} \pm 9.58$.

\begin{tabular}{|c|c|c|c|}
\hline & $\begin{array}{c}\text { Cases } \\
\text { (mean } \pm \text { SD) }\end{array}$ & $\begin{array}{c}\text { Controls } \\
\text { (mean } \pm \text { SD) }\end{array}$ & $\begin{array}{c}\text { P } \\
\text { value }\end{array}$ \\
\hline $\begin{array}{c}\text { Serum } \\
\text { phosphorus } \\
(\mathrm{mg} / \mathrm{dL})\end{array}$ & $5.74 \pm 1.35$ & $3.91 \pm 0.41$ & $<0.001$ \\
\hline $\begin{array}{c}\text { Serum calcium } \\
(\mathrm{mg} / \mathrm{dL})\end{array}$ & $7.75 \pm 0.74$ & $9.81 \pm 0.52$ & $<0.001$ \\
\hline \multicolumn{3}{|c|}{ Table 1: Comparison of Serum Phosphorus and } \\
Calcium Levels in Cases and Controls \\
\hline
\end{tabular}

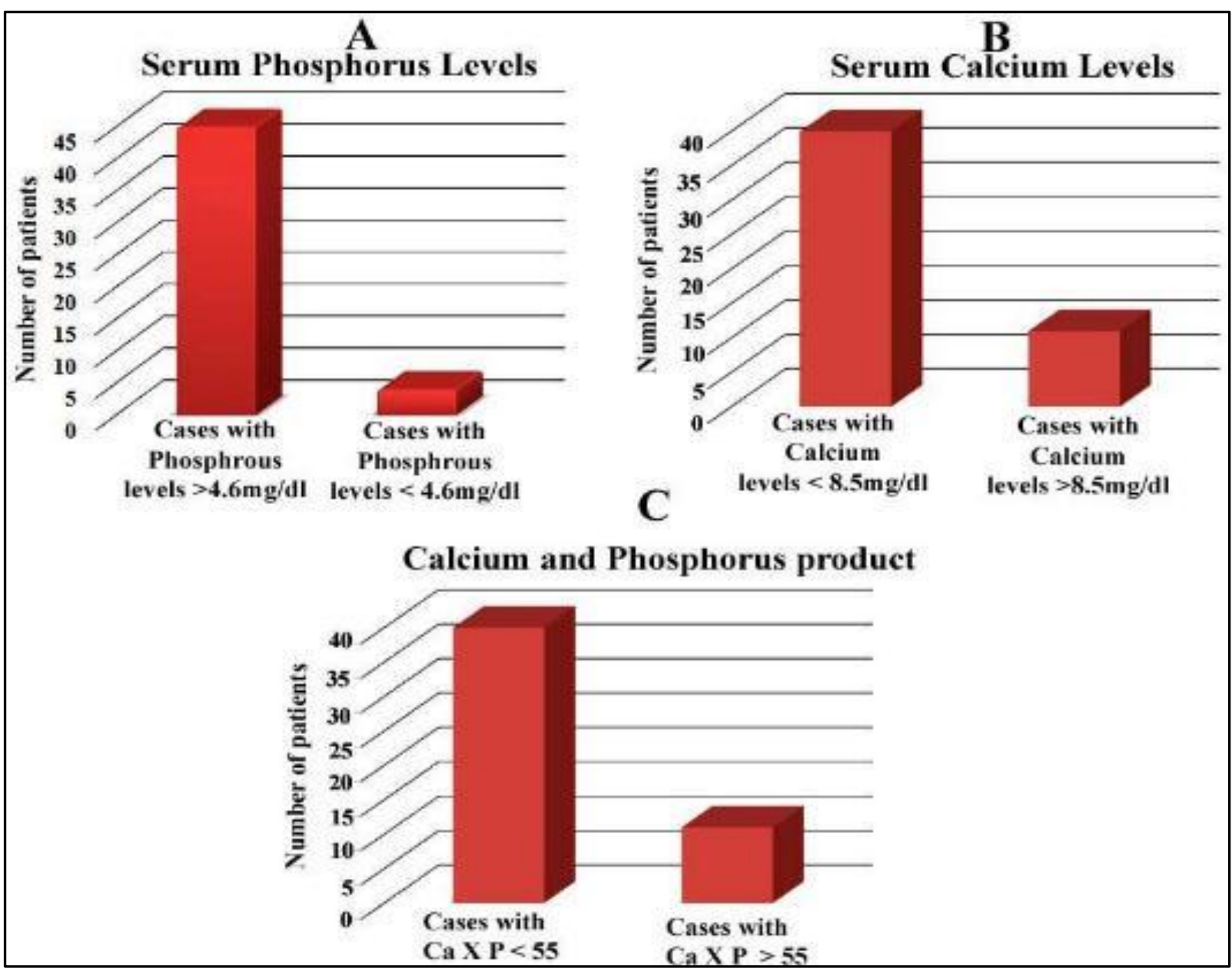

Fig. 1: Represents the Levels of Phosphorus

(A) Calcium

(B) Calcium and Phosphorus Product (CaXP)

(C) With Respect to KDOQI Guidelines

43 (96\%) patients had serum phosphorus levels above $4.6 \mathrm{mg} / \mathrm{dL}$ and only $2(4 \%)$ patients had serum phosphorus levels of $<4.6 \mathrm{mg} / \mathrm{dL}$ (Fig. 1A); 40 (89\%) patients had serum calcium levels below $8.5 \mathrm{mg} / \mathrm{dL}$ and only $5(11 \%)$ patients had serum calcium levels above $8.5 \mathrm{mg} / \mathrm{dL}$ with (Fig. 1A) (Fig. 1B); $40(89 \%)$ patients had CaXP below 55 and $5(11 \%)$ patients had CaXP above 55 (Fig. 1C). 


\section{DISCUSSION}

The clinical practice guidelines have been formulated by the National Kidney Foundation-Kidney Disease Outcomes Quality Initiative. The evidence-based guidelines thus framed has improved the diagnosis and treatment modalities of kidney disease, hence improved the lives of thousands of kidney patients.

This study has provided an insight into the status of existing practice of the guidelines. The current study showed that relatively large percentage of patients undergoing MHD were outside of the KDOQI guideline target ranges for serum $\mathrm{Ca}, \mathrm{P}$ levels, which was similar to the study by Kim et al.(14) Thus, the percentage of patients who were within the KDOQI guideline ranges were relatively modest: Ca 11\%; P 4\%. These data represent the current status of serum mineral control in our population undergoing MHD. Hence, a simplified medication adjustment according to certain ranges of serum phosphorus and calcium is needed for better long-term outcomes for patients undergoing MHD, which is also recommended by Hwang et al.(15)

In this study, the percentage of patients who were within the guideline ranges was much lesser than that observed in the Dialysis Outcomes and Practice Patterns Studies (DOPPSI) that was performed between 1996 and 2001, before the KDOQI guidelines were published.[7] which was also similar to a Multinational Observational Study.(16) In DOPPSI, the percentage of patients within the KDOQI guideline ranges were $40.5 \%$ for $\mathrm{Ca}, 40.8 \%$ for $\mathrm{P}, 56.6 \%$ for CaXP product.[11] The percentage of patients within the KDOQI guideline ranges in DOPPSII (2002-2004) were $42.5 \%$ for $\mathrm{Ca}, 44.4 \%$ for $\mathrm{P}$, $61.4 \%$ for the CaXP product.[11]

But the level of CaXP product was well within the KDOQI guidelines in 40 (89\%) patients; only $5(11 \%)$ patients had CaXP product level outside KDOQI guideline range.

The abnormalities in the serum levels of calcium and phosphorus in our patients indicates towards the presence of secondary hyperparathyroidism and mineral bone disease, which is also suggested by Silver et al.(17) Further ionized calcium is the set point of secondary hyperparathyroidism undergoing haemodialysis and the range of set point lies between $2.3-4.8 \mathrm{mg} / \mathrm{dL} .{ }^{(18)}$

These patients can be managed better by dietary phosphorus restriction, use of phosphate binders and adequate dialysis. The use of vitamin $\mathrm{D}$ receptor agonists is another important tool in preventing development of secondary hyperparathyroidism.

\section{CONCLUSION}

In conclusion, this study demonstrated the current status of serum Ca, P, CaXP product in MHD patients. As international practice guidelines were introduced, serum mineral profiles appeared to improve. However, relatively modest percentage of patients remain outside of the guideline's target ranges. Because these mineral abnormalities are associated with mineral bone disease and cardiovascular mortality, adequate management of mineral abnormalities should be promptly done in these patients.

\section{ACKNOWLEDGMENT}

We thank our Research Scientists, Dr. Geetha Bhaktha and Mrs. Manjula B. of Multidisciplinary Research Unit (MRU)-SIMS, Shivamogga in assisting the research work.

\section{REFERENCES}

1. Goodman WG, Goldin J, Kuizon BD, et al. Coronary artery calcification in young adults with end-stage renal disease who are undergoing dialysis. $\mathrm{N}$ Engl J Med 2000;342(20):1478-83.

2. Ishimura E, Taniwaki $\mathrm{H}$, Tabata $\mathrm{T}$, et al. Cross-sectional association of serum phosphate with carotid intimamedial thickness in haemodialysis patients. Am J Kidney Dis 2005;45(5):859-65.

3. Braun J, Oldendorf M, Moshage W, et al. Electron beam computed tomography in the evaluation of cardiac calcification in chronic dialysis patients. Am J Kidney Dis 1996;27(3):394-401.

4. Block GA, Hulbert-Shearon TE, Levin NW, et al. Association of serum phosphorus and calcium xphosphate product with mortality risk in chronic haemodialysis patients: a national study. Am J Kidney Dis 1998;31(4):607-17.

5. Ganesh SK, Stack AG, Levin NW, et al. Association of elevated serum PO4, Ca x PO4 product, and para- thyroid hormone with cardiac mortality risk in chronic haemodialysis patients. J Am Soc Nephrol 2001;12(10):2131-38.

6. Kestenbaum B, Sampson JN, Rudser KD, et al. Serum phosphate levels and mortality risk among people with chronic kidney disease. J AmSoc Nephrol 2005;16(2):52028.

7. National Kidney Foundation. K/DOQI clinical practice guidelines for bone metabolism and disease in chronic kidney disease. Am J Kidney Dis. 2000;42:S1-S201.

8. Kidney Disease: Improving Global Outcomes (KDIGO) CKD-MBD work group. KDIGO clinical practice guideline for the diagnosis, evaluation, prevention, and treatment of chronic kidney disease-mineral and bone disorder (CKDMBD). Kidney int 2009;76(suppl113):S1-S130.

9. Elder G, Faull R, Branley P, et al. Caring for Australasians with renal impairment (CARI). The CARI guidelines. management of bone disease, calcium, phosphate and parathyroid hormone. Nephrology (Carlton) 2006;11:S230-S261.

10. Fukagawa M, Yokoyama K, Koiwa F, et al. CKD- MBD Guideline Working Group. Japanese Society for Dialysis Therapy. Clinical practice guideline for the management of chronic kidney disease-mineral and bone disorder. Ther Apher Dial 2013;17(3):247-88.

11. Young EW, Akiba T, Albert JM, et al. Magnitude and impact of abnormal mineral metabolism in haemodialysis patients in the Dialysis Outcomes and Practice Patterns Study (DOPPS). Am J Kidney Dis 2004;44(5 Suppl 2):34-8.

12. Tentori F, Blayney MJ, Albert JM, et al. Mortality risk for dialysis patients with different levels of serum calcium, phosphorus, and PTH: the Dialysis Outcomes and Practice Patterns Study (DOPPS). Am J Kidney Dis 2008;52(3):51930.

13. Gallieni M, Cucciniello E, D’Amaro E, et al. Calcium, phosphate, and PTH levels in the haemodialysis population: a multicenter study. J Nephrol 2002;15(2):165-70.

14. Kim GH, Choi BS, Cha DR, et al. Serum calcium and phosphorus levels in patients undergoing maintenance haemodialysis: a multicentre study in Korea. Kidney Research and Clinical Practice 2014;33(1):52-57. 
15. Hwang E, Choi BS, Oh KH, et al. Management of chronic kidney disease-mineral and bone disorder: korean working group recommendations. Kidney research and clinical practice 2015;34(1):4-12.

16. Shaheen FA, Kurpad R, Al-Sayyari AA, et al. Multinational observational study on clinical practices and therapeutic management of mineral and bone disorders in patients with chronic kidney disease stages 4, 5, and 5D: the OCEANOS study. Saudi J Kidney Dis Transpl 2016;27(2):290-304.
17. Silver J, Naveh-Many T. FGF-23 and secondary hyperparathyroidism in chronic kidney disease. Nature Reviews Nephrology 2013;9(11):641-9.

18. Sudhakar T, Kandi S, Reddy KB, et al. The set point of intact parathyroid hormone-ionized calcium curve during the progression of secondary hyper-parathyroidism among patients undergoing haemo-dialysis. American Journal of Medical and Biological Research 2014;2(4):87-90. 